\title{
Monetary Policy: Its Impact On The Profitability Of Banks In India
}

Punita Rao, (Email: puni12@hotmail.com), K. J. Somaiya College Of Arts \& Commerce, Mumbai, India

\begin{abstract}
This purpose of this study is to investigate the impact of monetary policy on the profitability of banks in the context of financial sector reforms in India. We discuss the financial sector reforms and the implication of the banks, the various instruments of monetary policy in India, and the impact of monetary policy on the profitability of banks.
\end{abstract}

\section{INTRODUCTION}

$n$ the past decade, significant changes in the design and conduct of monetary policy have occurred around
the world. Many developing countries, including India have adopted an inflation targeting regime.

Monetary policy objectives have traditionally included promoting growth, achieving full employment, smoothing the business cycles, preventing financial crisis and stabilizing long term interest rates and the real exchange rate. Although some objectives are consistent with each other, others are not, for example, the objectives of price stability often conflicts with the objectives of interest rate stability and high short run employment. Monetary policy targets, as distinct from objectives, are proximate goals- goals that are not objectives in and of themselves but which, if attained, will work directly towards achieving the longer-term objectives of policy. Monetary policy targets are classified as either operating targets or intermediate targets. Intermediate targets are variables, although thought to affect the ultimate objectives of monetary policy, are not controlled directly by the Central Bank. They include various monetary aggregates and long-term interest rates. In contrast, operating targets are tactical goals that the Central Bank can influence better in the short run. Although Central Banks cannot use monetary policy instruments directly to intermediate targets, they can use them to affect operating targets, such as reserve money and short-term interest rates, which influence movements in intermediate variables. Monetary instruments that affect operating targets are generally classified as direct or indirect. Direct instruments function according to regulations that directly affect either interest rates or volume of credit (e.g. Interest rate ceilings and changes in the reserve requirements). These instruments have become increasingly ineffective as money and financial markets develop, besides, they create distortions, and promote financial disintermediation, fiscal dominance. Indirect instruments are termed as market based instruments since their use affect the market- determined price of bank reserves as the Central Bank engages in transactions with both financial and non-financial institutions. There are two main types of indirect instruments, open market operations and Central Bank lending policies - that are used to inject and absorb liquidity.

The monetary transmission process links monetary policy actions to the ultimate objectives of policy. The traditional textbook explanation concentrates on the demand for money, that is, the liability side of the financial system. However since the late 1980's, researchers have been re-examining this transmission process from the assets side of Bank's balance sheets, namely credit to the private sector. They have identified an additional channel of transmission for monetary policy, known as the credit channel with two implications that are of particular relevance for policy makers.

(1) In many instances credit may serve as a superior intermediate variable for monetary policy, as well as leading indicator for economic activity. Bernake and Blinder (1988) shows that if one considers the impact of 
monetary policy on the ability of the banking system to lend, credit succeeds as an intermediate variable where monetary aggregates fail, specifically, when demand for money is unstable, as in the case when a country is undergoing a process of financial development. Thus in these circumstances policymakers may get a clearer picture of inflation, a longer-term economic growth by observing credit rather than monetary aggregates.

(2) Identifying the credit channel of monetary transmission has permitted a greater understanding of the nature and characteristics of business cycles. As a series of studies following Bernake, Girtter, and Gilchrist (1999) during the late 1990's shows, the impact of monetary policy and other shocks to the macroeconomic tends to be stronger and more persistent than traditional models would predict, and the credit channel helps to explain this discrepancy. The credit channel contains an amplifying mechanism whereby difficulties in the real sector lead to tightness in the credit market, thus shrinking the credit available for investment, which in turn exacerberates the real sectors downturn. Furthermore, it is now apparent that shocks to bank credit itself may have a considerable impact on economic activity. Indeed, studies of recent slowdown in the bank credit in different region of the world show that regulatory changes as well as past financial distress may lead banks to adopt a more cautions approach to lending, with a visible impact on economic activity.

This purpose of this study is to indicate the impact of monetary policy on the profitability of banks in the context of financial sector reforms in India. In section 2 we discuss the financial sector reforms and the implication of the banks. In section 3 the various instruments of monetary policy in India is discussed. Section 4 we measure quantitatively the impact of monetary policy on the profitability of banks. Section 5 concludes the study.

\section{FINANCIAL SECTOR REFORMS AND BANKS}

The Indian Government undertook a comprehensive market oriented reforms program in 1991. It is vital to recognize that the most significant difference in the pre- and post liberalization period was that in the former investment were not market driven while in the latter period investment are market driven. The industrial licensing system insured that investment was consistent with plan targets and the financial plans ensured that the planned investment (in terms of sectoral targets) was realized. The entire financial system, including banks worked to realize planned investment targets in various sectors. In this period, the screening and monitoring functions of banks were substantially de- emphasized as the government directed a large part of bank lending. The post liberalization period witnessed a substantial deregulation of the financial sector along with radical reforms of trade and industrial policies, which has led investment to be completely market driven.

Prior to onset of reforms the banking sector, in India was dominated by 28 state owned commercial banks who accounted for 90 percent of deposits and advances. Private sector banks and foreign banks did exist but their operations, expansion, and possible new entry were severely restrained by the policy environment. In this period there were severe restrictions placed on the banks with regard to pricing and allocation of credit. Moreover, the sources of funds for banks too were highly restricted and regulated. Banks were not free to raise new equity and their participation in the money market was inhibited by government imposed ceilings on the interest rates in this market. It was only in 1989 that certificate of deposits (CD) were introduced but their market was again subjected to substantial restrictions. In fact the government through a detailed and a complicated administrative system determined all interest rates in the financial system.

On the balance of payment front even the current account was not convertible let alone the capital account. The RBI was forced to bring about changes in the monetary stance mainly through the Cash Reserve Ratio (CRR) as the low level of development of the government securities market ruled out the use of open market operations. In such a scenario, any withdrawl of reserves leads to an almost immediate curtailment of bank lending. But this would have nothing to do with the capital market imperfection.

As a part of ongoing reforms program in Jan 1993, the RBI set up detailed guidelines regarding the entry of new banks. Under the new guidelines entry by both private sector and foreign banks were allowed and this had an impact on the market structure of the banking sector. The share of government owned banks in total deposits and 
advances has fallen to below 80 percent in 2000. Financial liberalization has given much greater freedom to banks on both the assets and liabilities side of operations. Between 1991 and 1994, interest rates on banks loans were deregulated in a phased manner. In October 1994, interest rates on loans above 0.2 millions were completely deregulated. Deposits rates were also substantially freed from controls. All new banks were required to be incorporated under the Company's Act 1996, and their shares are required to be listed on stock markets. This has opened up a new source of funds hither to unavailable to banks (in the form of new equity issues) and in fact many government owned banks too have raised money. The market for CD has also been improved, through the removal of the bank specific limits on their issue in 1993. This has led to substantial activity in the primary market for CD's but the secondary market remains thin. The reform in the financial sector has led to creation of a well-regulated and deep market for government securities. Open market operations have become the predominant instrument through which the RBI implements monetary policy changes. In 1994, a separate supervisory body "Board of Financial Supervision" (BIFS) was established as an independent supervisory and monitoring body. This body exercises its powers of inspection and supervision with respect to all financial intermediaries including banks, development banks, and nonbanking financial companies.

As a direct outcome of the reforms process banks by 1994 had started competing for both loans and deposits. Moreover due to significant entry of new banks the competitive pressures increased quite substantially. With the reforms and subsequent maturing of the money markets and equity markets, banks have increasingly used these markets to raise funds. This exposes banks to the consequences of imperfections inherent in these markets. These imperfections form the underpinnings of the credit channel of monetary transmission in general and bank lending channel in particular.

We now present in brief the changing structure of Banks in India.

\section{Structure Of Banks In India}

\begin{tabular}{|c|c|c|c|c|c|c|}
\hline & \multicolumn{3}{|c|}{ Public Sector } & \multicolumn{3}{|c|}{ Private Sector } \\
\hline & 1995 & 2000 & 2003 & 1995 & 2000 & 2003 \\
\hline Total Deposits & 84.19 & 79.07 & 76.05 & 6.38 & 12.19 & 13.20 \\
\hline Total Advances & 83.45 & 77.24 & 74.10 & 6.56 & 12.23 & 13.43 \\
\hline Total Assets & 84.00 & 77.30 & 74.00 & 5.93 & 11.85 & 12.00 \\
\hline \multirow[t]{2}{*}{ No. of Banks } & 69.77 & 69.89 & 69.90 & 6.51 & 7.67 & 8.00 \\
\hline & \multicolumn{3}{|c|}{ Foreign Banks } & \multicolumn{3}{|c|}{ Regional Banks } \\
\hline & 1995 & 2000 & 2003 & 1995 & 2000 & 2003 \\
\hline Total Deposits & 6.76 & 5.29 & 6.01 & 2.67 & 3.45 & 3.50 \\
\hline Total Advances & 7.22 & 7.81 & 7.84 & 2.78 & 2.72 & 2.76 \\
\hline Total Assets & 7.25 & 7.19 & 7.50 & 2.82 & 3.66 & 3.50 \\
\hline No. of Banks & 0.26 & 0.27 & 1.45 & 6.27 & 23.42 & 24.1 \\
\hline
\end{tabular}

\section{MONETARY POLICY- REVIEW OF THE OPERATION OF INSTRUMENTS}

\section{Bank Rate}

Bank rate is the rate at which the central bank of the country is prepared to buy or rediscount the eligible bills of exchange. It operates on the cost of credit directly by altering the cost at which the central banks credit is available to the commercial banks. In practice, it may, however, be extremely difficult to predict the effect of change in the bank rate on public sector banks borrowings and money supply as it banks borrowings depend on the degree of dependence on borrowed reserves and the sensitivity of banks demand for borrowed reserves to the difference between their lending and borrowing rates.

Since 1997 the Bank Rate has been reactivated as the principal signaling device of the monetary policy stance across the interest rate structure in consonance with inflationary expectations and the liquidity situation. The 
Bank Rate was reduced in stages to 6.25 percent in October 2002, the lowest rate since May 1973, and by a further 25 basis points in April 2003. The Bank Rate has been reduced by 500 basis pints in the last five years. Banks have the freedom to fix interest rates on term deposits, with flexibility in offering as approved by their boards. The only regulated rate is on the saving accounts with cheque facility. The reduction in the administered interest rates on small saving announced in the Union Budget 2003-04 and moderate inflation enabled a 50 basis point reduction in the saving deposit rate to 3.5 percent per annum from March 1, 2003

\section{Lending Rates}

The downward rigidity in lending rates is reflected in spreads over the prime lending rates (PLR). Unconscionably wide spreads are unwarranted in a period of low inflation. Moreover, the adversely impact the overall credit portfolio of Banks and obscure the appropriate pricing of loans. In this context, banks are required to announce the maximum spread over the PLR for all advances except consumer credit. Structural impediments to flexibility in the interest rate structure include the high carrying cost o long term deposits mobilised in the past by banks at fixed interest rates and non- performing assets. Long term deposits (over 1 year) contracted at fixed rates constitute around 70 percent of the aggregate deposits of the banking system. Advances in the form of short term credit at fixed rate constitute around 40 percent of the total loan portfolio. There is also a lack of depositor interest in flexible deposit schemes in an environment of low inflation and falling nominal interest rates. The carrying cost of NPA and the tendency to load additional risk premium against possibilities of further accumulation of NPAs forces up lending rates. Besides NPAs, persistence of high operating costs also results in a significant drag on commercial bank's ability to lower lending rates.

\section{Reserve Requirements}

With the help of this technique the Central bank can affect the credit creating capacity of the banks The Central Bank exercises direct control over the liquidity of the banks through two complementary methods.

\section{Cash Reserve Ratio (CRR)}

Under section 42(i) of the Reserve Bank of India Act, scheduled banks are required to keep a certain percentage of their demand and time liabilities with the RBI. An increase in the CRR is an indicator of restrictive monetary policy. The policy of varying CRR may take the form of rise in CRR against the total demand and time liabilities. Or, the RBI may instruct the banks to maintain with it additional cash reserves computed with reference to the excess of their total demand and time liabilities over the level of such liabilities on a base data by the RBI, subject to the condition that incremental do not exceed 100 percent of the excess and that the total reserve do not exceed 15 percent of their demand and time liabilities. This has changed thereafter. The medium term objective is, however to reduce the CRR to the statutory minimum level of 3.0 percent. Accordingly, on a review of the developments in the international and domestic financial markets, a 75 basis point reduction in the CRR during June to November, 2002 was followed by a further 25 basis point cut from June 14,2003 taking the level of the CRR down to 4.5 percent. The minimum daily maintenance of CRR was raised to 80 percent of the average daily requirement for all the days of the reporting fortnight with effect from the fortnight beginning November 16, 2002. This was subsequently lowered to 70 percent with effect from the fortnight beginning December 28, 2002. The payment of interest on eligible CRR balances maintained by the banks was changed from quarterly basis to monthly basis from April 2003.

\section{Statutory Liquidity Ratio (SLR)}

The Banks in India are required statutorily to maintain a prescribed minimum proportion of their total demand and time liabilities (L) in the form of liquid assets. These liquid assets consists of excess reserves (ER), unencumbered government and other approved securities (I) and other current account balances with other banks (CB)

Thus, $\mathrm{SLR}=\frac{\mathrm{ER}+\mathrm{I}+\mathrm{CB}}{\mathrm{L}}$ 
SLR operates as an instrument of monetary control by affecting the freedom of the banks to sell government securities and borrow against these from RBI. This ratio has remained unchanged at a minimum of 25 percent of net demand and time liabilities (NDTL) since October 1997.From 1 2003, all scheduled urban co-operative banks have to maintain the entire SLR holdings of 25 percent of NDTL in government and other approved securities only. This is true for Regional Rural Banks.

\section{Open Market Operations (OMO)}

This refer to the purchase and sale of government securities by the Central Bank to alter the reserve base of the banks and hence to check their capacity to expand credit. Every open market purchase of securities by the Central Bank increases the currency held by the public and cash reserves of the banks and every sale reduces it. Prior to liberalization in India, the open market operations of the Reserve Bank have not been very powerful instrument of monetary control because of the underdeveloped nature of money and capital markets. Moreover these operations were dominated by considerations of public debt management rather than monetary control. Net open market sales were higher during 2002-03 than in the previous year and in excess of the Reserve Bank's net subscription to primary issuance of government securities by Rs, 17,605 crore. The OMO sales of May31- June 1, 2002 were conducted to neutralize the impact of CRR cut of 50 basis points on June 1, 2002. In order to ensure that a sufficient stock of marketable securities would be available in the portfolio of the Reserve Bank for conducting OMO from time to time, the government of India converted Rs. 40,000 crore of 4.6 percent Special securities issued earlier to the Reserve bank into marketable securities at various maturities at the prevailing yields.

\section{EMPIRICAL STUDY}

In order to study the impact of monetary policy on bank's profitability various instruments of monetary policy have been assumed to be independent variables in the regression equation. Thus the regression equation to be estimated for the purpose takes the following form.

$\mathrm{P}_{\mathrm{t}}=\beta_{0}+\beta_{1} \mathrm{BR}+\beta_{2} \mathrm{LR}+\beta_{3} \mathrm{CRR}+\beta_{4} \mathrm{SLR}$

Where

$P_{t}$ is the profitability of the banks

LR is the lending rates of the banks

$\mathrm{CRR}$ is the cash reserve ratio

SLR is the statutory ratio

The regression coefficient of all the independently variables are found to be statistically significant. However when we look at the $\mathrm{R}^{2}$ value the private sector banks with respect to the SLR has the maximum value. The study indicates a greater impact of general credit control on the private sector banks, but since the various policy instruments are used as a package, it may sound unwise to arrive at any such deductions. A multiple regression analysis has been done to find out if it would provide better evaluation. The regression estimates are presented in Table 2. Following observation can be made from the step wise multiple regression analysis. There has been an improvement in the $\mathrm{R}^{2}$ value in the case of public sector. The coefficient of the lending rates is positive which indicates a fall in lending rates will reduce the profitability of the banks. When we include the Bank Rate, CRR and SLR the regression coefficient is insignificant to explain the relationship between bank profitability and the monetary policy instrument in the case of public sector banks. It can be concluded that banking is still regulated and controlled in terms of a strict credit policy followed by the Reserve Bank of India to combat inflationary pressures.

The results of the estimated regression equation are presented in Table 1 and Table 2. 
Table 1

Regression Estimates Of Independent Variables Regressed Independently

\begin{tabular}{|c|c|c|c|c|c|c|c|}
\hline Intercept & BR & LR & CRR & $\begin{array}{l}\text { c Sector } \\
\text { SLR }\end{array}$ & $\mathbf{R 2}$ & DW & F-stats \\
\hline 2.216 & $\begin{array}{l}-1.936 \\
(-3.30)\end{array}$ & & & & 0.497 & 1.200 & 10.89 \\
\hline $\begin{array}{l}2.034 \\
(3.38)\end{array}$ & & $\begin{array}{l}1.244 \\
(-2.98)\end{array}$ & & & 0.447 & 1.264 & 8.90 \\
\hline $\begin{array}{l}1.779 \\
(9.53)\end{array}$ & & & $\begin{array}{l}-1.283 \\
(-8.38)\end{array}$ & & 0.864 & 1.68 & 70.35 \\
\hline 1.56 & & & & $\begin{array}{l}-0.45 \\
(-2.47)\end{array}$ & 0.357 & 0.70 & 6.12 \\
\hline
\end{tabular}

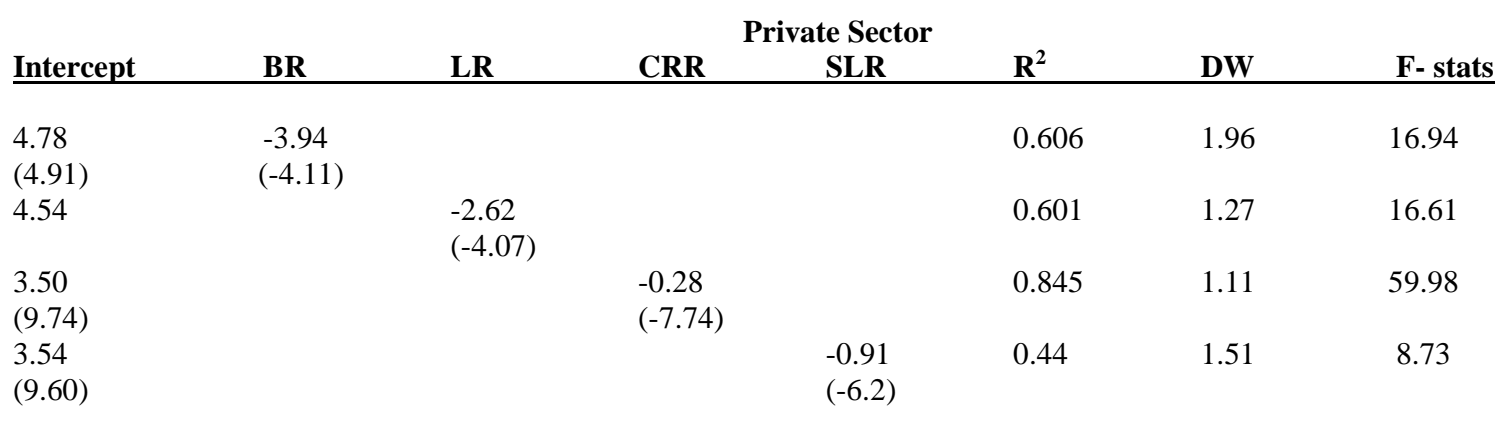

Figures in the parenthesis are the $\mathrm{t}$ values.

Table 2

Regression Estimates Of The Step-Wise Multiple Regression Estimates Analysis

Public Sector

$\begin{array}{llllllll}\text { Intercept } & \text { BR } & \text { LR } & \text { CRR } & \text { SLR } & \mathbf{R}^{2} & \text { DW } & \text { F- stats } \\ 14.08 & & & & & & & \\ (3.74) & -0.83 & 14.31 & -16.81 & -0.12 & 0.947 & 2.58 & 36.07 \\ 11.90 & (-1.12) & (2.71) & (-5.78) & (-0.82) & & & \\ (4.50) & -0.34 & 11.00 & -18.36 & & 0.94 & 2.64 & 49.58 \\ 10.71 & (-0.78) & (3.25) & (-8.21) & & & \\ (2.30) & 0.78 & & -18.21 & 0.18 & 0.899 & 2.13 & 26.70 \\ & (1.36) & & (-4.89) & (1.43) & & & \end{array}$

Private Sector

$\begin{array}{llllllll}\text { Intercept } & \text { BR } & \text { LR } & \text { CRR } & \text { SLR } & \mathbf{R}^{2} & \text { DW } & \text { F- stats } \\ 4.58 & -0.31 & 0.20 & -0.15 & -0.58 & 0.88 & 1.77 & 15.04 \\ (4.47) & (-1.56) & (1.44) & (-2.02) & (-1.39) & & & 1.90 \\ 3.59 & -0.90 & 0.05 & -0.28 & & 0.85 & & 17.58 \\ (4.69) & (-0.71) & (0.57) & (-3.51) & & & 1.06 & 17.25 \\ 4.09 & -0.08 & & -0.18 & -0.012 & 0.851 & & \end{array}$

Figures in the parenthesis are the $\mathrm{t}$ values. 


\section{CONCLUSIONS}

The overall monetary and macroeconomic conditions are, at present quite satisfactory and in line with the policy expectations. India needs to further improve upon the financial sector reforms. Nevertheless the Reserve Bank would continue to keep a constant watch on the domestic and external situation. Monetary policy is guided by the objective of provision of adequate liquidity to meet credit growth and support investment demand in the economy while monitoring carefully the movements in the price level. The policy stance continues to be one of preference for a soft and flexible interest rate environment within the framework of macroeconomic stability.

\section{REFERENCES}

1. Bernake, Blen and A. S. Blinder. (1988) Is It Money or Credit or Both or Neither. Credit Money and Aggregate Demand, AEA Papers and Proceedings.

2. Bernake, S. Gilchrist, and M. Gertler (1999) The Financial Accelerator in a Quantitative Business Cycles Framework, in Handbook of Macroeconomics Vol. 1 edited by J. B. Taylor and M. Woodford.

3. Denburg and Mc Dougal. (1980) Macroeconomics. Prentice Hall

4. Mishkin, Fredric (1995) The Channels of Monetary Transmission Lessons for Monetary Theory, NBER Working Papers.

5. $\quad$ Several issues of RBI Bulletin and Annual Reports.

6. Tobin, James (1978) Monetary Policy and the Economy: The Transmission Mechanism, Southern Economic Journal 44

\section{NOTES}




\section{NOTES}

